\title{
Front Matter: Volume 9337
}

, "Front Matter: Volume 9337," Proc. SPIE 9337, Nanoscale Imaging, Sensing, and Actuation for Biomedical Applications XII, 933701 (7 April 2015); doi: $10.1117 / 12.2192901$

SPIE. Event: SPIE BiOS, 2015, San Francisco, California, United States 


\title{
PROGRESS IN BIOMEDICAL OPTICS AND IMAGING
}

\section{Nanoscale Imaging, Sensing, and Actuation for Biomedical Applications XII}

\author{
Alexander N. Cartwright \\ Dan V. Nicolau \\ Editors
}

9 and 12 February 2015

San Francisco, California, United States

Sponsored and Published by

SPIE 
The papers included in this volume were part of the technical conference cited on the cover and title page. Papers were selected and subject to review by the editors and conference program committee. Some conference presentations may not be available for publication. The papers published in these proceedings reflect the work and thoughts of the authors and are published herein as submitted. The publisher is not responsible for the validity of the information or for any outcomes resulting from reliance thereon.

Please use the following format to cite material from this book:

Author(s), "Title of Paper," in Nanoscale Imaging, Sensing, and Actuation for Biomedical Applications XII, edited by Alexander N. Cartwright, Dan V. Nicolau, Proceedings of SPIE Vol. 9337 (SPIE, Bellingham, WA, 2015) Article CID Number.

ISSN: 1605-7422

ISBN: 9781628414271

Published by

SPIE

P.O. Box 10, Bellingham, Washington 98227-0010 USA

Telephone +1 3606763290 (Pacific Time) · Fax +1 3606471445

SPIE.org

Copyright (C) 2015, Society of Photo-Optical Instrumentation Engineers.

Copying of material in this book for internal or personal use, or for the internal or personal use of specific clients, beyond the fair use provisions granted by the U.S. Copyright Law is authorized by SPIE subject to payment of copying fees. The Transactional Reporting Service base fee for this volume is $\$ 18.00$ per article (or portion thereof), which should be paid directly to the Copyright Clearance Center (CCC), 222 Rosewood Drive, Danvers, MA 01923. Payment may also be made electronically through CCC Online at copyright.com. Other copying for republication, resale, advertising or promotion, or any form of systematic or multiple reproduction of any material in this book is prohibited except with permission in writing from the publisher. The CCC fee code is $1605-7422 / 15 / \$ 18.00$.

Printed in the United States of America.

Publication of record for individual papers is online in the SPIE Digital Library.

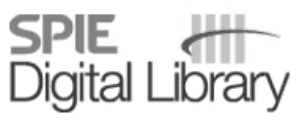

SPIEDigitallibrary.org

Paper Numbering: Proceedings of SPIE follow an e-First publication model, with papers published first online and then in print. Papers are published as they are submitted and meet publication criteria. A unique citation identifier (CID) number is assigned to each article at the time of the first publication. Utilization of CIDs allows articles to be fully citable as soon as they are published online, and connects the same identifier to all online, print, and electronic versions of the publication. SPIE uses a six-digit CID article numbering system in which:

- The first four digits correspond to the SPIE volume number.

- The last two digits indicate publication order within the volume using a Base 36 numbering

system employing both numerals and letters. These two-number sets start with 00, 01, 02, 03, 04, $05,06,07,08,09,0 A, 0 B \ldots 0 Z$, followed by 10-1Z, 20-2Z, etc.

The CID Number appears on each page of the manuscript. The complete citation is used on the first page, and an abbreviated version on subsequent pages. 


\title{
Contents
}

\author{
$\checkmark$ Authors \\ vii Conference Committee
}

\section{SESSION $1 \quad$ NANOSCALE IMAGING AND NANOSPECTROSCOPY}

933702 Confocal Raman microscopy and hyperspectral dark field microscopy imaging of chemical and biological systems (Invited Paper) [9337-1]

933703 Scanning localized magnetic fields in microfluidic system using single spin in diamond nanocrystal [9337-2]

933705 Biological super-resolution imaging by using novel microsphere-embedded coverslips [9337-4]

933709 Nano-imaging collagen by atomic force, near-field and nonlinear microscope [9337-8]

9337 OA Extraordinary transmission-based super-resolved axial imaging using subwavelength metallic nanoaperture arrays [9337-9]

\section{SESSION 2 BIOSENSING WITH NANOSTRUCTURES AND NANOPARTICLES}

9337 OD Label-free monitoring of individual DNA hybridization using SERS [9337-12]

9337 OE Determination of thickness and density of a wet multilayer polymer system with subnanometer resolution by means of a dual polarization silicon-on-insulator microring [9337-13]

9337 OG Determination of the persistence length of actin filaments on microcontact printed myosin patterns [9337-17]

POSTER SESSION

$9337 \mathrm{Ol}$ Persistent luminescence in nanophosphors for long term in-vivo bio-imaging (Invited Paper) [9337-15]

9337 OJ Performance evaluation for different sensing surface of BICELLs bio-transducers for dry eye biomarkers [9337-19]

9337 ON Imaging highly absorbing nanoparticles using photothermal microscopy [9337-23]

933700 Systematic study and quantification of optical forces on porous silicon nanoparticles [9337-24] 
Proc. of SPIE Vol. $9337933701-4$

Downloaded From: https://www.spiedigitallibrary.org/conference-proceedings-of-spie on 26 Apr 2023 Terms of Use: https://www.spiedigitallibrary.org/terms-of-use 


\section{Authors}

Numbers in the index correspond to the last two digits of the six-digit citation identifier (CID) article numbering system used in Proceedings of SPIE. The first four digits reflect the volume number. Base 36 numbering is employed for the last two digits and indicates the order of articles within the volume. Numbers start with 00, 01, 02, 03, 04, 05, 06, 07, 08, 09, 0A, 0B...0Z, followed by 10-1Z, 20-2Z, etc.

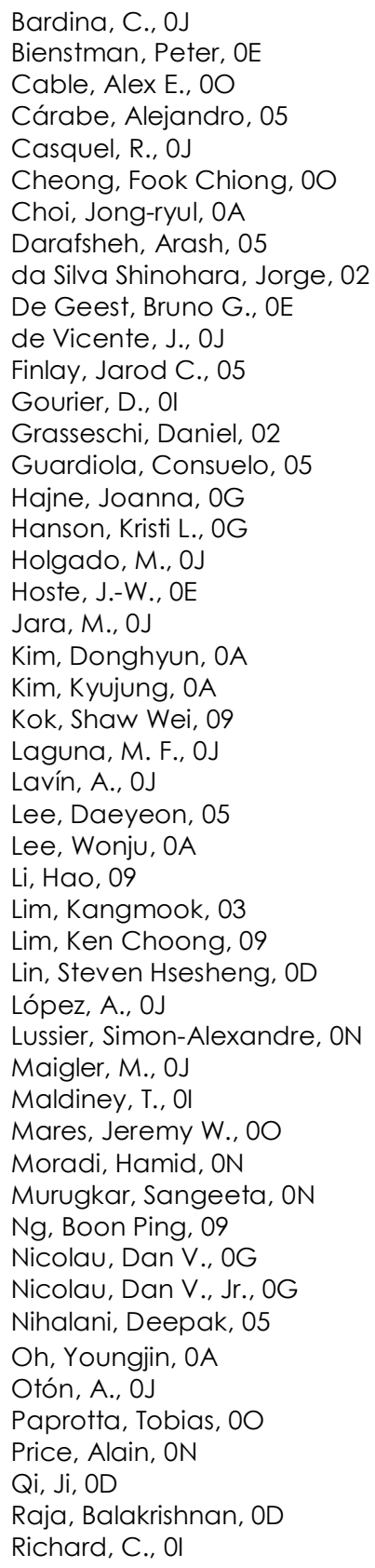

\author{
Riesgo, T., OJ \\ Santamaría, B., OJ \\ Santos, Greggy M., OD \\ Sanza, F. J., OJ \\ Scherman, D., Ol \\ Schumacher, Jens, 00 \\ Shapiro, Benjamin, 03 \\ Sharma, S. K., Ol \\ Shih, Wei-Chuan, OD \\ Soria, J., OJ \\ Strych, Ulrich, OD \\ Suarez, T., OJ \\ Tang, Jinkai, 09 \\ Taylor, Jacob, 03 \\ Teston, E., Ol \\ Toma, Henrique E., 02 \\ van Zalinge, Harm, OG \\ Viana, B., 01 \\ Waks, Edo, 03 \\ Wang, Qijie, 09 \\ Weiss, Sharon M., 00 \\ Willson, Richard C., OD \\ Zeng, Jianbo, OD \\ Zhang, Ying, 09 \\ Zhao, Fusheng, OD
}


Proc. of SPIE Vol. $9337933701-6$

Downloaded From: https://www.spiedigitallibrary.org/conference-proceedings-of-spie on 26 Apr 2023 Terms of Use: https://www.spiedigitallibrary.org/terms-of-use 


\title{
Conference Committee
}

\author{
Symposium Chairs
}

James G. Fujimoto, Massachusetts Institute of Technology

(United States)

R. Rox Anderson, Wellman Center for Photomedicine, Massachusetts General Hospital (United States) and Harvard School of Medicine (United States)

Program Track Chairs

Paras N. Prasad, University at Buffalo (United States)

Dan V. Nicolau, McGill University (Canada)

Conference Chairs

Alexander N. Cartwright, University at Buffalo (United States)

Dan V. Nicolau, McGill University (Canada)

Conference Program Committee

Vamsy P. Chodavarapu, McGill University (Canada)

Piotr A. Grodzinski, National Cancer Institute (United States)

Sung Jin Kim, University of Miami (United States)

Brian D. MacCraith, Dublin City University (Ireland)

Paulo C. Morais, Universidade de Brasília (Brazil)

Paras N. Prasad, University at Buffalo (United States)

Sharon M. Weiss, Vanderbilt University (United States)

\section{Session Chairs}

1 Nanoscale Imaging and Nanospectroscopy

Alexander N. Cartwright, University at Buffalo (United States)

2 Biosensing with Nanostructures and Nanoparticles

Dan V. Nicolau, McGill University (Canada) 
Proc. of SPIE Vol. $9337933701-8$

Downloaded From: https://www.spiedigitallibrary.org/conference-proceedings-of-spie on 26 Apr 2023 Terms of Use: https://www.spiedigitallibrary.org/terms-of-use 